\title{
TEST OF FAITH
}

\author{
The heat is on.
}

\section{BY BRIAN P. FRANK}

I must not fail. Sixth-year graduate student Vikram Singh was sweating profusely, not just from the heat of the nearby bonfire or the glowing bed of coals spread before him. Around him, the faculty members and students of the Chemical Engineering Department clapped and chanted the ritual songs while Professor Markson leapt about in a frenzy as she led the undergraduates, her long grey hair released from its customary tight bun. Her face was streaked with ceremonial paint in red and black, the school colours. The old bat looked utterly terrifying, worse than she had during his candidacy exams. Vikram stood barefoot and wore only the traditional loincloth.

All I have to do is walk across the coals. My ancestors in India did this for hundreds of years simply through the power of their belief. So why not me?

Of course, most of India was under water now, and he had grown up a Greenhouse refugee in Kansas. But he had climbed out of the camps, found scholarships to get himself here to the Institute and onward for graduate work until only one final barrier remained. But if he couldn't pass this test, it would all be for nothing. The noise grew louder, Professor Markson leaping higher until Vikram was sure she was going to give herself a coronary. It suddenly stopped as Professor Li, Vikram's thesis adviser, strode into the firelight and began the ritual speech:

"We gather here tonight to test the faith of Vikram Singh. Since the time of George the Second" - there was a chorus of enthusiastic boos and hisses from the crowd - "we have known that it is not enough for scientists and engineers to choose cold detachment. Those were dark days of research suppressed, of scientists persecuted for speaking truths that could have saved us all. And what is the result? Global disaster so vast that we still live with the consequences. It must not happen again."

"Never again," the crowd murmured.

"We must stand against those who would promote ignorance for selfish ends. We must have true faith! Vikram Singh!" Li barked, "Where do you place your faith?"

Vikram licked dry lips and gave the

response. "I place my faith in the facts as revealed by science."

Li went on: "Like the martyrs of science - Hypatia, Archimedes, Galileo, DeMorgan - we must be willing to give our very lives for our faith. Now you too must face this ultimate trial."

No one spoke. No one moved. This was their department's most sacred tradition, and everyone knew it. Other disciplines had their own rituals, but this was the Chemical Engineering way.

Then Li shouted: "Let the final test begin!"

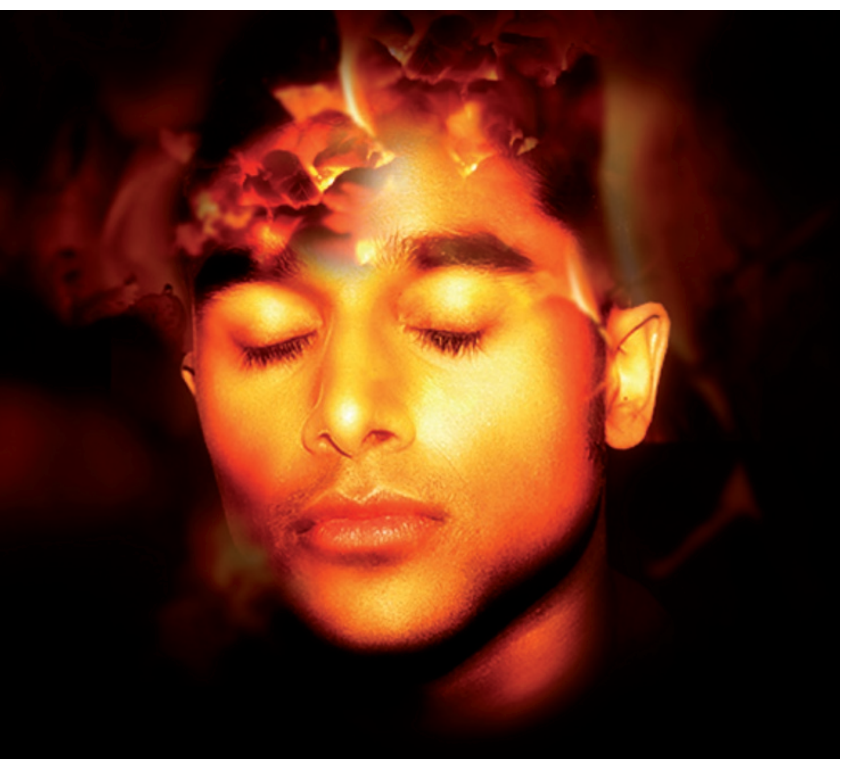

Vikram turned to face the coals as the crowd roared its approval. He'd told no one about that horrifying and unforgettable night when he was seven and the fire had raced unchecked through the camp.

If I believe strongly enough, then the coals won't burn me. He took a deep breath and without thinking stepped onto the bed of coals and began to walk across. Just keep moving...

He made it halfway across before the terror pounced. I'm standing on a bed of red-hot coals!

It was like that awful night in the camp, only a thousand times worse. The fear raged about him like a storm, and in his panic

$\rightarrow$ NATURE.COM

Follow Futures on

Facebook at:

go.nature.com/mtoodm everything seemed to slow and stop around him. It was only a second or two of suspended time, but within it Vikram thought harder and faster than he ever had in his life.

He had to have faith; if he only had faith he could do this. Where do you place your faith? he asked himself, and automatically his mind answered, I place my faith in the facts as revealed by science. And then it hit him.

I believe in thermodynamics.

Thermal effusivity. Unsteady state heat flow. Specific heat capacities. Leidenfrost effect. The equations blazed right there in his mind, basics from a course drilled into every first-year student at the Institute. The ash surrounding the coals has a low thermal conductivity so it acts as an insulator. The water in my tissues has a very high heat capacity but the coals have a very low one, therefore my foot's temperature will change less than that of the coals. Water has a high thermal conductivity so the heat will be carried away from the bottom of my feet; coals have a low thermal conductivity so the only heat comes from the surface of the coals actually in contact with my feet. You didn't need faith to believe that firewalking worked. All you really needed was to understand thermodynamics.

No, it was more than that. This wasn't just about his understanding, it really was about his faith. Not his faith in his beliefs; that was the mistake they had made in the last century, that somehow their beliefs about the facts would change them. Instead, this was a test of his belief in science and its ability to reveal the facts. So did he truly believe in the facts as revealed by science? Enough to walk across fire?

The moment of paralysis stretched and broke, but he knew his answer now and confidence surged through him. Unafraid, he crossed the remainder of the coals to collapse at last, smiling and unhurt, into the arms of the crowd. Then Li pushed through and grasped Vikram's hands and held them high over his head like a championship boxer as he shouted: "I present to you Vikram A. Singh, graduate student no more. Congratulations, Vikram A. Singh, PhD!"

Brian P. Frank holds a PhD in chemical engineering, and conducts research into aerosol-phase environmental nanoparticles. This story is dedicated to his late mentor, thermodynamics professor Hank Van Ness. 